\title{
The Impact of Governance on the Research Performance of European Universities in Cross-Country Comparisons
}

\author{
Jan Sedláček ${ }^{1}$
}

\begin{abstract}
The article concentrates on the impact of selected aspects of governance - the level of autonomy and the involvement of stakeholders in the internal governance of a university - on the research performance of universities measured by indicators of international university rankings in cross-country comparisons. The analyses are geographically situated in Europe. They follow two paths which are from the theoretical point of view based on the concepts of the principal-agent problem and stakeholder theory. Using linear regression, the author identifies statistically significant aspects of governance and compares them with results of previous studies. The findings serve as a basis for a discussion regarding how to create appropriate conditions for universities in order to improve their prospects for international success in research. The limitations of the results relating to the data, methodology and their application in the European context are discussed and general recommendations are formulated.
\end{abstract}

Key words: governance, research performance, universities

JEL Classification: I23, I28

Received: 21 June 2017 / Accepted: 10 August 2017 / Sent for Publication: 8 December 2017

\section{Introduction}

It seems important to search for information regarding which aspects of university governance are influential in respect to the performance of universities if any regulator wants to define the governance of universities in the public interest based on rational arguments free from the influence of pressure groups and individuals competing in conflicting political, bureaucratic and academic arenas. Surprisingly, research on the relationship of governance and the performance of universities in international comparisons is quite rare, as mentioned in Progress in higher education reforms across Europe, Governance and Funding reform volume II: Methodology, performance data, literature survey, national system analyses and case studies (CHEPS, 2008b), and as can be found by checking the Web of Science and Scopus from 2009 to 2016.

\footnotetext{
${ }^{1}$ University of Economics Prague, Faculty of International Relations, Department of World Economy, Nám. W. Churchilla 4, 13067 Praha 3, Czech Republic,jan_sedlacek@seznam.cz
}

(C) 2017 by the authors; licensee Review of Economic Perspectives / Národohospodářský obzor, Masaryk University, Faculty of Economics and Administration, Brno, Czech Republic. This article is an open access article distributed under the terms and conditions of the Creative Commons Attribution 3.0 license, Attribution - Non Commercial - No Derivatives. 
There are, however, some inspiring publications of Aghion's team: Why reform Europe's universities? (Aghion et al. 2007), Higher Aspirations: An Agenda for Reforming European Universities (Aghion et al. 2008), The Governance and performance of the Research Universities: Evidence from Europe and the U. S. (Aghion et al. 2009) and The governance and performance of universities: evidence from Europe and the US (Aghion et al. 2010). Selected passages of these publications focus on the relationship or causality between research universities' performance in the USA and Europe as measured by the Academic Ranking of World Universities (abbreviated as ARWU) and characteristics of university governance such as age, status (public or private), budget autonomy, building ownership, hiring autonomy, wage-setting autonomy, percentage of faculty holding internally conferred Ph.D. degrees (so called endogamy = hiring their own graduates) and proportion of internal board members. Among the findings (Aghion et al. 2007; 2008), there is a positive correlation between performance and the following indicators: budget per student, budget autonomy, wage-setting autonomy and hiring autonomy. On the contrary, there is a negative correlation between performance and the public status of a university (private are better in comparison) and the degree of endogamy in faculty hiring. The main finding is that budget autonomy doubles the positive effect of the budget per student on the performance of a university. In the context of the USA, it was found that allocation of funds based on competition leads to an improvement in research performance (Aghion et al. 2009; 2010).

This article makes use of the idea of Aghion to explore which aspects of university governance are significant in relation to research performance.

\section{Research Problem}

Governance of universities has been, is and probably will be a frequently discussed topic among academic staff. This article tries to contribute to these discussions with arguments based on new empirical research. The aim of this article is to identify aspects of governance that play a statistically significant role in creating an environment suitable for top-ranked universities in European countries to succeed in cross-country comparisons of research performance.

Although Aghion's publications (Aghion et al. 2007; 2008; 2009; 2010) were the main sources of inspiration, the research problem is solved in a different way. This changes the scope of this research, i.e. different data sets and analytical methods are used.

The aspects of governance taken into consideration are based on the outputs of two comparative studies: University Autonomy in Europe (EUA 2015) and The extent and impact of higher education governance reform across Europe (CHEPS, 2006b). The performance indicators are derived from the Academic Ranking of World Universities and the CWTS Leiden Ranking.

Two hypotheses based on different theoretical concepts are formulated to support the solution of the research problem:

Hypothesis H1: The performance of European universities in research in cross-country comparisons is statistically significantly influenced by the autonomy of a university. 
The first hypothesis is based on the principal-agent concept (Ross, 1973). The principals are mainly the state or other regulators. Universities are agents, whose responsibility is to fulfil the expectations of regulators. The autonomy of a university (organizational, financial, staffing and academic autonomy) represents to what extent it is controlled or how much freedom it has in decision-making. In principle, the degree of autonomy implicitly indicates how much the regulators have to spend on monitoring costs (the higher the degree of autonomy, the lower the monitoring costs).

Hypothesis H2: The performance of European universities in research in cross-country comparisons is statistically significantly influenced by the involvement of stakeholders in the internal governance of a university.

The stakeholder theory provides the theoretical background for the second hypothesis. If an organization wants to be successful it must take into consideration the needs of the stakeholders (Freeman, 2010). The question is: which of the stakeholders should or should not be involved in the internal governance in relation to creating a suitable environment for high research performance.

Regarding terminology, the word governance is defined as "formal and informal exercise of authority under laws, policies and rules that articulate the rights and responsibilities of various actors, including the rules by which they interact" (Eurydice 2008, p. 12). This covers both the level of a university and regulation, i.e. internal and external governance (CHEPS, 2008a).

Regarding context, it must be emphasized that the objective of the article is neither to compare individual universities nor whole national higher education systems. This research concentrates on the dominant sector of the higher education systems - research universities in selected European countries that are successful in selected indicators of international rankings relating to research. This means that the heterogeneity of higher education systems in individual European countries (including different types of universities differing in their missions, status etc.) is not part of the research focus of this article. This article is also limited in that it does not cover the evaluation of other activities performed by universities - teaching or the so-called "third mission". Thus, the approach to the analysis is simplified and the European countries are compared based on the success of their national research universities in research performance as a whole.

The key question is whether the chosen aspects of governance which are simplified and generalized for universities of the given countries might be statistically significant determinants for creating a suitable environment for supporting universities in international competition measured by selected indicators of international university rankings.

The data sets and methods are described in detail and discussed from the point of view of their weaknesses and strengths in the following sections of the article.

\section{Data sets}

The data sets are derived or taken from the outputs of expert teams. The following section explains the adaptation of the data for international comparisons so that they could be used for regression analysis; it explains the reasons why they were selected and discusses their interpretation, which is limited both in terms of the methodology of their 
original construction and in terms of their adaptation for the analytical context of the research.

\section{Performance indicators}

Performance indicators represent dependent variables in the regression models. Three indicators for research performance of universities in international comparisons were selected. Each of them is created using a different methodology and covers different aspects of university research performance.

The first two indicators are derived from the Academic Ranking of World Universities.

They are as follows:

- $\quad$ Papers published in Nature and Science (abbreviated as N and S)

"The number of papers published in Nature and Science... To distinguish the order of author affiliation, a weight of $100 \%$ is assigned for corresponding author affiliation, $50 \%$ for first author affiliation (second author affiliation if the first author affiliation is the same as corresponding author affiliation), $25 \%$ for the next author affiliation, and $10 \%$ for other author affiliations. Only publications of 'Article' and 'Proceedings Paper' types are considered" (ARWU, 2016).

- Papers indexed in Science Citation Index-Expanded and Social Science Citation Index (abbreviated as PUB)

"Total number of papers indexed in Science Citation Index-Expanded and Social Science Citation Index... Only publications of 'Article' and 'Proceedings Paper' types are considered. When calculating the total number of papers of an institution, a special weight of two was introduced for papers indexed in Social Science Citation Index” (ARWU, 2016).

These indicators have been selected from indicators of the Academic Ranking of World Universities, because they are based on respected publicly available sources and because their connection with the governance data based on a time frame is justifiable.

The third indicator is based on the CWTS Leiden Ranking:

- The number of a university's publications that, "compared with other publications in the same field and in the same year, belong to the top $1 \%$ most frequently cited" (Leiden ranking, 2016). The indicator reflecting the proportion of co-authorship, called fractional counting, is used. This means that coauthored papers have less weight in the calculation, (abbreviated as Ptop1).

"The Leiden Ranking is based on publications in the Web of Science database produced by Clarivate Analytics... The Leiden Ranking uses the Science Citation Index-Expanded, the Social Sciences Citation Index, and the Arts \& Humanities Citation Index. Only publications of the Web of Science document types article and review are taken into account... We refer to the publications in this subset as core publications. Core publications are publications in international scientific journals in fields that are suitable for citation analysis" (Leiden Ranking, 2016).

The main reason for the selection of the indicator was to take into consideration the most frequently cited publications which would reflect the specifics of individual fields. 
The performance of the relevant universities is calculated for a given country and is then divided by the country's population, in order to create a per capita indicator.

As can be seen in the description of the sources of the indicators, these indicators are constructed as to be internationally comparable. However, their disadvantage is that they cover only some outputs of the performance in research and do not include all the disciplines due to their sources of data. In addition, it must be pointed out that publishing strategies in different universities and different countries reflect different attitudes towards disciplines. Moreover, different criteria in universities and countries influence the output of academic staff because they are crucial in advancing careers (Frey and Eichinger 1993).

\section{Governance indicators}

\section{University autonomy indicators}

Governance indicators represent independent variables. The governance indicators concerning university autonomy are adopted from the so-called University Autonomy Tool (EUA 2015). The indicators can be classified into two types - overall indicators, which represent organizational, financial, staffing and academic autonomy, and partial indicators which quantify the data of detailed aspects of overall indicators. The indicators are as follows:

Organizational autonomy: selection procedure for the executive head, selection criteria for the executive head, dismissal of the executive head, term of office of the executive head, external members in university governing bodies, capacity to decide on academic structures, capacity to create legal entities. (EUA, 2015)

Financial autonomy: length of public funding cycle, type of public funding, ability to borrow money, ability to keep surplus, ability to own buildings, tuition fees for national/EU students at Bachelor's/Master's/doctoral level, tuition fees for non-EU students at Bachelor's/Master's/doctoral level. (EUA, 2015)

Staffing autonomy: recruitment procedures for senior academic staff, recruitment procedures for senior administrative staff, salaries for senior academic staff, salaries for senior administrative staff, dismissal of senior academic staff, dismissal of senior administrative staff, promotion procedures for senior academic staff, promotion procedures for senior administrative staff. (EUA, 2015)

Academic autonomy: overall student numbers, admissions procedures at Bachelor's level, admissions procedures at Master's level, introduction of programmes at Bachelor's level, introduction of programmes at Master's level, introduction of programmes at doctoral level, termination of degree programmes, language of instruction at Bachelor's level, language of instruction at Master's level, selection of quality assurance mechanisms, selection of quality assurance providers, capacity to design the content of degree programmes. (EUA, 2015)

\section{Indicators of stakeholder involvement in aspects of internal university governance}

Stakeholder involvement in internal aspects of governance of a university has been quantified according to benchmarking conducted by CHEPS (2006). It uses three op- 
tions - the stakeholders are not involved, are involved to some degree or are involved to a large degree. The aspects of internal governance concerned have been adopted without any adjustment. They are as follows: mission/strategy, internal governance structure, new study programmes, quality assurance, finance/resources allocation, human resources management, student access/selection, public private partnership. On the other hand, the stakeholder groups have been slightly adjusted. They are state/ministries, central management, middle management, staff members, students and external subjects. The adjustments made concern external subjects (all the external subjects excluding the state/ministries have been united into one category) and staff (the academic and nonacademic staff have been united). The adjustment is a reaction to differences in provided information; for example, some of the countries unite the academic and nonacademic staff, some of them do not. The basis for the indicators is the quantification of the degree of involvement: no involvement $=0$ points; involvement to some degree $=$ 0.5 points; involvement to a large degree $=1$ point. Two kinds of indicators have been created: partial indicators, which quantify the degree of stakeholders' involvement in individual internal aspects of governance, and overall indicators, which are the sum of the partial indicators of the stakeholder group.

As has been mentioned, the governance indicators were originally constructed for crosscountry comparisons, which means that they are generalized for universities of a given European country regarding both for external and internal governance. Therefore, they do not provide detailed information concerning the heterogeneity of higher education systems and the detailed differences among universities, which are to be expected due to the university's status (public/private), size, mission etc. Unlike Aghion's studies (2007; $2008 ; 2009 ; 2010)$ the data provide general analytical categories, which causes the analyses to be simplified.

\section{Economic conditions}

The analysis is supplemented by the independent variable: expenditures on tertiary education per capita, so as not to omit important economic circumstances.

\section{Choice of countries}

The choice of countries reflects the availability of data both on performance and aspects of governance. Therefore, the selection of the countries for each of the two analytical lines is different.

The computations concerning the university autonomy and research performance include the following countries: Austria, Belgium Flanders, the Czech Republic, Finland, France, Germany Hesse, Germany North Rhine West, Ireland, Italy, the Netherlands, Norway, Poland, Portugal, Spain, Sweden and the United Kingdom of Great Britain England.

Whereas the computations of stakeholders' involvement in internal university governance and research performance include: Austria, Belgium Flanders, Belgium French Community, the Czech Republic, Finland, France, Germany, Ireland, Italy, Norway, Poland, Portugal, Slovenia, Spain, Sweden, the United Kingdom of Great Britain.

To assess the relevance and validity of the data and its sources, see Appendix 1 and 2. 


\section{Analytical methods}

As has been mentioned, one of the objectives of the article is to find out whether there exists an impact of selected aspects of governance (four types of autonomy and stakeholder involvement in the internal governance of a university) on the research performance of universities in international comparisons.

The main analytical method is a regression analysis that is used for testing the hypotheses. The characteristics of the data sets, which are described above in detail, show that governance data sets provide tens of indicators, which are used as independent variables of two types - overall and partial. At the same time, the number of countries included in the calculation (16 for each of the analytical parts) is relatively small. This is due to data representing both performance and governance not being available for all European countries. In this situation, there is a need to reduce the number of independent variables, which is done via a stepwise regression, and to eliminate the independent variables that are not statistically significant.

The preparation of the models, i.e., the selection of independent variables, is a combination of qualitative assessment of the context and calculations of ANOVA and correlation. Regarding the presentation of the results, only models that meet two conditions are presented: all their dependent variables are statistically significant at the 5\% level and the outliers have been eliminated. (In all cases Norway is the only outlier). The hypotheses are tested at the 5\% level on the basis findings derived from a cluster of models. Either overall or partial dependent variables are used in each individual model.

The procedure described above is advantageous due to the variety of independent variables and their combinations, the impact on research performance of which may not have been expected and can be explored. On the other hand, the method could pose the risk of creating models that might be correct in a mathematical sense but might in fact be distant from academic reality and would have no value in considerations regarding the application of possible findings. Moreover, the results must be judged bearing in mind all the limitations of the data sets, described above, and that the analytical section is a combination of analytical categories whose data sets have been derived from the outputs of previous authors and which are not the results of this author's research.

\section{Results}

The results of the analyses, that is the regression models, are presented in the tables in order to provide an overview and ease the reader's orientation both in regard to testing the hypotheses and assessing the information value of the results, if there is any. A presentation of regression models with detailed information is available in Appendix 3.

\subsection{University autonomy and research performance}

As been mentioned above, the first analytical part tests hypothesis H1: The performance of European universities in research in cross-country comparisons is statistically significantly influenced by the autonomy of a university. 
Three regression models were created. Table 1 shows results of regression that demonstrate that some aspects of university autonomy along with expenditures on tertiary education per capita positively influence the research performance. The university autonomy indicators that have been identified as statistically significant independent variables are: financial autonomy (statistically significant at 0.01 , model 1 ), autonomy in tuition fees for national/EU students at doctoral level (statistically significant at 0.01 , model 2) and autonomy in recruitment procedures for senior academic staff (statistically significant at 0.05 , model 3 ).

Table 1 Autonomy of a university

\begin{tabular}{|c|c|c|c|}
\hline Model number (dependent variable) & 1 (Ptop1) & 2 (Ptop1) & 3 (PUB) \\
\hline Constant & $-4.26794^{* * *}$ & $-2.400^{* * *}$ & $-2.550^{* * *}$ \\
\hline Expenditures on tertiary education per capita & $8,84935 \mathrm{e}-05^{\star * *}$ & $7.92573 \mathrm{e}-05^{\text {***}}$ & $5.65241 \mathrm{e}-05^{\star * *}$ \\
\hline Financial autonomy & $0.0348346^{* * *}$ & & \\
\hline $\begin{array}{l}\text { Autonomy in recruitment procedures for senior } \\
\text { academic staff }\end{array}$ & & & $0.018^{* *}$ \\
\hline $\begin{array}{l}\text { Autonomy in tuition fees for national/EU stu- } \\
\text { dents at doctoral level }\end{array}$ & & $0.015^{* * *}$ & \\
\hline R-squared & 0.892 & 0.903 & 0.859 \\
\hline Adjusted R-squared & 0.874 & 0.887 & 0.835 \\
\hline No. of observations & 15 & 15 & 15 \\
\hline
\end{tabular}

Note: The level of statistical significance is indicated as follows: ${ }^{*}=0.1,{ }^{* *}=0.05,{ }^{* \star *}=0.01$.

Source: author's calculations

Hypothesis H1: The performance of European universities in research in cross-country comparisons is statistically significantly influenced by the autonomy of a university is accepted on the basis of models 1-3.

\subsection{Stakeholder involvement in internal university governance and research per- formance}

The second analytical part widens the focus of analysis. It tests hypothesis H2: The performance of European universities in research in cross-country comparisons is statistically significantly influenced by the involvement of stakeholders in the internal governance of a university.

Eleven regression models have been created demonstrating the positive impact of expenditures on tertiary education per capita on research performance complemented by the influence of other independent variables.

Table 2 shows that the involvement of students in internal governance (in general) (positive, statistically significant at 0.05 , model 4 ) and the involvement of students in quality assurance (positive, statistically significant at 0.05 , models 5 and 6) both affect research performance. 
Table 2 Student involvement in internal governance

\begin{tabular}{|l|c|c|c|}
\hline Model number (dependent variable) & 4 (Ptop1) & 5 (Ptop1) & 6 (N and S) \\
\hline Constant & $-2.183^{* * *}$ & $-2.052^{* *}$ & $-0.760^{* * *}$ \\
\hline Expenditures on tertiary education per capita & $7.77714-05^{* * *}$ & $7.70254 \mathrm{e}-08^{* * *}$ & $2.70817 \mathrm{e}-05^{* * *}$ \\
\hline Overall inv. of students in internal governance & $0.201^{* *}$ & & \\
\hline Involvement of students in quality assurance & & $1.028^{* *}$ & $0.286^{* *}$ \\
\hline R-squared & 0.831 & 0.832 & 0.842 \\
\hline Adjusted R-squared & 0.803 & 0.805 & 0.815 \\
\hline No. of observations & 15 & 15 & 15 \\
\hline
\end{tabular}

Source: author's calculations

Table 3 shows that state involvement in internal governance (in general) is a negative factor, statistically significant at 0.01 (both in models 7 and 8).

Table 3 State involvement in internal governance in general

\begin{tabular}{|l|c|c|}
\hline Model number (dependent variable) & 7 (N and S) & 8 (PUB) \\
\hline Constant & 0.067 & 0.686 \\
\hline Expenditures on tertiary education per capita & $2.25497 \mathrm{e}-05^{* * *}$ & $6.04281 \mathrm{e}-05^{* * *}$ \\
\hline Overall inv. of state in internal governance & $-0.090^{* * *}$ & $-0.294^{* * *}$ \\
\hline R-squared & 0.905 & 0.903 \\
\hline Adjusted R-squared & 0.889 & 0.886 \\
\hline No. of observations & 15 & 15 \\
\hline
\end{tabular}

Source: author's calculations

Table 4 shows a negative impact on research performance by state involvement in human resources management (statistically significant at 0.05, models 9 and 10) and state involvement in finance/resources allocation (statistically significant at 0.01, model 11).

Table 4 State involvement in human resources management and finance/resources allocation

\begin{tabular}{|l|c|c|c|}
\hline Model number (dependent variable) & 9 (Ptop1) & 10 (N and S) & 11 (N and S) \\
\hline Constant & -0.739 & -0.348 & $-0.458^{* *}$ \\
\hline Expenditure on tertiary education per capita & $7.01212 \mathrm{e}-05^{* * *}$ & $2.46908 \mathrm{e}-05^{* * *}$ & $2.74711 \mathrm{e}-05^{\star * *}$ \\
\hline Involvement of state in HRM & $-0.876^{* *}$ & $-0.279^{* *}$ & \\
\hline Inv. of state in finance/resources allocation & & & $-0.295^{\star * *}$ \\
\hline R-squared & 0.811 & 0.847 & 0.861 \\
\hline Adjusted R-squared & 0.779 & 0.821 & 0.838 \\
\hline No. of observations & 15 & 15 & 15 \\
\hline
\end{tabular}

Source: author's calculations 
Table 5 shows a negative impact on research performance by state involvement in new study programmes (statistically significant at $0.01,0.01$ and 0.05 , models 12,13 and 14) and a positive effect of the involvement of external subjects in mission/strategy (statistically significant at 0.05 , models 12 and 13 ).

Table 5 State involvement in new study programmes and external subject involvement in mission/strategy

\begin{tabular}{|l|c|c|c|}
\hline Model number (dependent variable) & 12 (Ptop1) & 13 (N and S) & 14 (PUB) \\
\hline Constant & -0.746 & $-0.478^{\star *}$ & -0.985 \\
\hline Expenditures on tertiary education per capita & $6.44238 \mathrm{e}-05^{\star * *}$ & $2.40221 \mathrm{e}-05^{\star * *}$ & $7.20055 \mathrm{e}-05^{\star \star *}$ \\
\hline Involvement of state in new study programmes & $-1.259^{* * *}$ & $-0.295^{* *}$ & $-0.820^{\star *}$ \\
\hline Inv. of external subjects in mission/strategy & $0.858^{\star *}$ & $0.284^{\star *}$ & \\
\hline R-squared & 0.938 & 0.899 & 0.860 \\
\hline Adjusted R-squared & 0.921 & 0.872 & 0.837 \\
\hline No. of observations & 15 & 15 & 15 \\
\hline
\end{tabular}

Source: author's calculations

Hypothesis H2: The performance of European universities in research in cross-country comparisons is statistically significantly influenced by the involvement of stakeholders in the internal governance of a university is accepted on the basis of models 4-14.

\section{Discussion and general recommendations}

Although the performed calculations have brought results that seem logical, it must be emphasized before formulating general recommendations that there are some limitations in the interpretation that relate to the data, methodology and context.

First of all, the author of the article uses secondary data which are adapted for the purpose of the article. The data provide cross-country comparisons of top-ranked universities; however, they do not cover the complicated academic reality in its entirety. This affects the interpretation of both the aspects of governance, which are generalized for a given country and thus, cannot contain complete information on the heterogeneity of given higher education systems and their diverse higher education institutions, and the research performance indicators which concentrate on publishing from different perspectives and thus, though important, concern only some of the research outputs.

Secondly, analysing the data through models is a simplification in exploring the research problem. The methodology of the analyses - that is, stepwise regression - helps in searching for a convenient combination with statistically significant independent variables influencing the dependent variables. However, although the preparation of the analyses is accompanied with qualitative considerations, it can occur that some important factors are not detectable with the methods used and remain hidden.

Thirdly, regarding contextual limitations, the calculations cover the period from 2005 to 2012 and are geographically situated in Europe. However, not all the European coun- 
tries are involved due to relevant data sets not being available. The European context itself is unique because of the traditions embedded in individual higher education systems.

Due to the limitations mentioned above, it is desirable to compare the results of the two analytical lines and to look over the findings together with the publications by Aghion at al. (2007; 2008; 2009; 2010), to find out whether there are similar, supplementary or contradictory findings relating to the factors describing the same areas.

If the results of the two analytical parts relating to similar governance areas are compared, reaffirming complementary findings (statistically significant at least at 0.05) can be identified:

- the positive impact of financial autonomy and the negative impact of state involvement in finance/resources allocation within a university,

- the positive impact of autonomy in recruitment procedures for senior academic staff and the negative impact of state involvement in human resources management.

Regarding the comparison with Aghion's publications (Aghion at al. 2007; 2008; 2009; 2010), it is evident that the amount of funds (in the case of Aghion, budget per student and in the case of the article, expenditures on tertiary education per capita) is a key factor. Regarding the results of the regression analyses there is a concurence of positive impact of budget autonomy (Aghion at al. 2007; 2008) and financial autonomy and the negative role of state involvement in finance/resources allocation within a university.

In principle, there are similarities to be seen in the positive correlation between wagesetting and hiring autonomy of universities and research performance (Aghion at al. $2007 ; 2008$ ) and this paper's results - the positive impact of indicators relating to staffing autonomy and the negative impact of state involvement in internal university governance in human resources management.

In addition to the findings showing that the indicators have counterparts in both analytical parts of this article and Aghion's publications (Aghion at al. 2007; 2008), there are some other interesting findings that can be interpreted from a different point of view such as: the positive role of students (overall and quality assurance) and the negative impact of the state (overall, human resources, finance/resources allocation, new study programmes). A positive impact of external subjects in relation to mission/strategy has also been identified, which seems reasonable, as external subjects usually possess important information and considerable influence on the external environment that, to some extent, regulates universities.

The analyses have provided findings that can be used to formulate general recommendations for the governance of universities in order to create suitable conditions for high research performance in international competition. However, they should be judged in the context of a given European country. The areas for recommendations are as follows:

\footnotetext{
Amount of funds

- Financial autonomy

- Staffing autonomy

- Quality assurance
} 
- $\quad$ Accreditation process of study programmes

- $\quad$ Strategy and mission

- $\quad$ Students versus state

- Support for research from the point of view of the connection between education and research activities

The results of the analyses are ordered according to the individual areas for which general recommendations have been formulated.

\section{Amount of funds}

Expenditures on tertiary education per capita are a positive factor in all of the models (statistically significant at 0.01 ). Therefore, it is a fundamental prerequisite to increase the amount of funds at least to the level of other competing countries if a country wants its universities to achieve excellent results in international comparisons of research success.

\section{Financial autonomy}

The positive impact of financial autonomy (model 1, statistically significant at 0.01 ) and autonomy in tuition fees for national/EU students at doctoral level (model 2, statistically significant at 0.01 ) on the research performance of universities in international comparisons has been demonstrated. These findings can be supplemented by the observed negative impact of state involvement in finance/resources allocation (model 11, statistically significant at 0.01 ). It can be recommended that the external regulation of funds should be decreased, i.e. that universities should be given the authority to decide on the allocation of their own funds independently.

\section{Staffing autonomy}

The indicators that have been identified as statistically significant at 0.05 - autonomy in recruitment procedures for senior academic staff (model 3, positive) and involvement of the state in human resources management (models 9 and 10, negative) - serve as an argument to lower regulation in human resources management. It can be recommended that authority and responsibility in human resources management be delegated to universities and state influence in this area be eliminated.

\section{Quality assurance}

The involvement of students in quality assurance (models 5 and 6, statistically significant at 0.05 ) positively influences the conditions for achieving success in research performance in international comparisons. Therefore, in general, it can be recommended that students become involved in this area.

\section{Accreditation process of study programmes}

The negative impact of the involvement of the state in new study programmes (models 12,13 and 14 - statistically significant at $0.01,0.01$ and 0.05 ) on the performance of universities in research in international competition provides an argument for recommending the delegation of responsibilities and authority in these aspects of governance to universities. 


\section{Strategy}

The involvement of external subjects in mission/strategy (models 12 and 13 - statistically significant at 0.05 ) positively influences the conditions for universities to achieve excellent outputs in research in international comparisons. Therefore, it can be recommended that the role of external subjects in this aspect of governance be strengthen.

\section{Students versus state}

Regarding stakeholders, it has been found that the influence of students is positive: the involvement of students in internal governance (in general) (model 4 - statistically significant at 0.05) and the involvement of students in quality assurance (models 5 and 6 - statistically significant at 0.05 ). This contrasts with the negative influence of the state: involvement of the state in finance/resources allocation (model 11, statistically significant at 0.01), involvement of the state in human resources management (models 9 and 10 , negative, statistically significant at 0.05 ; the involvement of state in internal governance (in general) (models 7 and 8, negative, statistically significant at 0.01 and 0.01 ) and involvement of the state in new study programmes (models 12, 13 and 14, negative, statistically significant at $0.01,0.01$ and 0.05 ). In general, it would be sensible to strengthen the role of students and weaken the role of the state in the internal governance of a university.

\section{Connection between education and research}

Considering the connection between education and research (as a specific feature of a university), it has been demonstrated that some aspects of governance relating to education influence the performance in research in international comparisons. They are: the involvement of students in internal governance (in general) (model 4 - statistically significant at 0.05 ) and the involvement of students in quality assurance (models 5 and 6 - statistically significant at 0.05 ) and involvement of the state in new study programmes (models 12, 13 and 14, negative, statistically significant at 0.01, 0.01 and 0.05). Therefore, it can be recommended that regulators pay attention to the connection between education and research when regulation of universities is formulated, especially in the area of research funding and the authority of the state and its distribution among ministries.

\section{Conclusion}

This article provides the results of research on the impact of governance on the research performance of universities in international comparisons. The results are achieved with regression analyses that use aspects of governance (university autonomy and stakeholder involvement, supplemented by data on expenditures on tertiary education) as independent variables and performance in research (derived from international university rankings) as dependent variables.

In general, the analyses have demonstrated that university autonomy and the limiting of state influence in internal university governance are essential if universities are to achieve excellent research results in international competition in the European context. The most important positive variable, which is the fundamental factor for reaching international success, is expenditures on tertiary education per capita. 
As for autonomy, the most important positive determinants can be found in financial and staffing autonomy.

As for the involvement of stakeholders in internal governance, the state involvement is a negative factor in general and in individual aspects of governance - new study programmes, human resources management, and allocation of finance/resources. On the other hand, the involvement of students is positive both in general and, specifically, in quality assurance. One of the interesting results is the positive role of external subjects regarding the strategy/mission of a university.

As for the testing of the hypotheses:

Hypothesis H1: The performance of European universities in cross-country comparisons in research is statistically significantly influenced by the autonomy of a university is accepted on the basis of models 1-3.

Hypothesis H2: The performance of European universities in research in cross-country comparisons is statistically significantly influenced by the involvement of stakeholders in the internal governance of a university is accepted on the basis of models 4-14.

A comparison of the two analytical parts leads to the conclusion that the results are similar or supplementary in financial autonomy $\mathrm{x}$ finance/resources allocation and staffing autonomy $\mathrm{x}$ human resources. The positive impact of financial autonomy and the positive correlation with indicators relating to staffing autonomy have also been demonstrated by Aghion et al. (2007; 2008).

General recommendations for universities regarding successful research performance in international comparisons, which should be judged with knowledge of the limitations of the data sets, the analytical methods and the context of a given European country, are as follows:

- $\quad$ to increase the amount of funds,

- to delegate responsibility to universities in the areas of human and financial resources,

- to decrease the involvement of the state in internal university governance,

- $\quad$ to increase the involvement of students,

- $\quad$ to increase the role of external subjects in matters of strategy/mission.

All the recommendations could contribute to important considerations by higher education regulators about the relevance and meaningfulness of external and internal governance of universities, especially considering the monitoring costs relating to the aspects of governance that should not be interfered with by a top-down approach (relating to the principal-agent problem) and the state involvement in internal aspects of governance that should be decreased (relating to the theory of stakeholders).

This article has brought new contributions to a discussion about the governance of universities. In spite of the fact that the findings seem to be reasonable, it is recommended that more research be done in different locations and over different time-spans, using different analytical methods and data sets. Future studies could confirm, supplement or contradict the findings presented in the article. 
Acknowledgements: For helpful comments and suggestions, I thank Mr. Stanislav Šaroch.

Funding: This article was supported by the project of the Faculty of International Relations, University of Economics: New Trends of Governance in the Light of Financial and Debt Crisis. Project registration number: F2/7/2014.

Disclosure statement: No potential conflict of interest was reported by the author.

\section{References}

AGHION, P., DEWATRIPONT, M., HOXBY, C., MAS-COLlEL, A., SAPIR, A. (2007). Why reform Europe's universities? [online] The Bruegel Policy Brief Series. Issue 2007/4. Available at: http://bruegel.org/wpcontent/uploads/imported/publications/pbf_040907_universities.pdf [Accessed: 5/5/2016]

AGHION, P., DEWATRIPONT, M., HOXBY, C., MAS-COLlEL, A., SAPIR, A. (2008). Higher Aspirations: An Agenda for Reforming European Universities. Bruegel Blueprint Series. vol. 5, ISBN 978-9-078910-07-7.

AGHION, P., DEWATRIPONT, M., HOXBY, C., MAS-COLlEL, A., SAPIR, A. (2009). The Governance and performance of the Research Universities: Evidence from Europe and the U. S. [online] NBER Working Paper No. 14851. Issued in April 2009. Available https://dash.harvard.edu/bitstream/handle/1/12502061/Governance\%20and\%20Peforma nce\%20of\%20Universities.pdf [Accessed: 5/5/2016]

AGHION, P., DEWATRIPONT, M., HOXBY, C., MAS-COLlEL, A., SAPIR, A. (2010). The governance and performance of universities: evidence from Europe and the US. Economic Policy. 1 January 2010, vol. 25, issue 61, pp.7-59.

ARWU [Shanghai Academic Ranking of World Universities]. (2016). [online] Copyright (C) 2016 Shanghai Ranking Consultancy. Available at: http://www.shanghairanking.com/\# [Accessed: 30/6/2016]

BFG [Belgian Federal Government] - Statistics Belgium: Population résidente de droit au ler janvier, par commune, par région: 1990-2009 [online] (C) 2013 Belgian Federal Government.

http://statbel.fgov.be/fr/modules/publications/statistiques/population/population__chiffres_population_1990-2009.jsp [Accessed: 5/5/2016]

CHEPS Consortium. (2006a). The extent and impact of higher education governance reform across Europe, Final report to the Directorate-General for Education and Culture of the European Commission. Part One: Comparative Analysis and Executive Summary. Contract: 2006 - 1407 / 001 - 001 S02-81AWB. [online] Available at: http://doc.utwente.nl/60095/1/Enders06extent1.pdf [Accessed: 5/5/2016]

CHEPS Consortium. (2006b). The extent and impact of higher education governance reform across Europe, Final report to the Directorate-General for Education and Culture of the European Commission. Part Two: Summaries of the Quick Scan Surveys on 
governance reform in 32 European countries. Contract: 2006 - 1407 / 001 - 001 S0281AWB. [online] Available at: http://doc.utwente.nl/60096/1/Enders06extent2.pdf [Accessed: 5/5/2016]

CHEPS Consortium. (2006c). The extent and impact of higher education governance reform across Europe Final report to the Directorate-General for Education and Culture of the European Commission. Part Three: Five case studies on governance reform. Contract: 2006 - $1407 / 001-001$ S02-81AWB. [online] Available at: http://vrt112546.servidoresdns.net/sites/default/files/extend-and-impact-highereducation-governance-reform-across-europe-iii_0.pdf [Accessed: 5/5/2016]

CHEPS Consortium. (2006d). The extent and impact of higher education governance reform across Europe, Final report to the Directorate-General for Education and Culture of the European Commission. Part Four: Governance Reform Survey Results. Contract: $2006-1407 / 001-001$ S02-81AWB. [online] Available at: http://doc.utwente.nl/60095/1/Enders06extent1.pdf [Accessed: 5/5/2016]

CHEPS Consortium. (2008a) Progress in higher education reform across Europe. Governance Reform. Volume 1: Executive Summary main report. The report to the Directorate-General for Education and Culture of the European Commission. Contract: 2008 - 3543/001 - 001 ERA-ERPROG. [online] Available at: http://www.rivistauniversitas.it/files/fileusers/Governance\%20reform.pdf [Accessed: 5/5/2016]

CHEPS Consortium. (2008b). Progress in higher education reform across Europe. Governance and funding reform. Volume 2: Methodology, performance data, literature survey, national system analyses and case studies. The report to the DirectorateGeneral for Education and Culture of the European Commission. Contract: 2008 3543/001 - 001 ERA-ERPROG a Contract: 2008 -3544/001 -001 ERA-ERPROG. [online] Available at: https://www.utwente.nl/bms/cheps/publications/Publications\%202010/Funding\%20Ref orm/FUN\%20vol\%202\%20Methodology,\%20perfomance\%20data.pdf cessed: 5/5/2016]

CHEPS Consortium. (2008c). Progress in higher education reform across Europe. Governance Reform. Volume 3: Governance fiches. The report to the DirectorateGeneral for Education and Culture of the European Commission. Contract: 2008 3543/001 - 001 ERA-ERPROG. [online] Available at: http://doc.utwente.nl/88697/1/GOV\%20vol\%203\%20Governance\%20fiches.pdf [Accessed: 5/5/2016]

EUA [European Association of Universities]. (2015). University autonomy in Europe [online] (C) EUA Available at: http://www.university-autonomy.eu/ [Accessed: 30/6/ 2015]

EURYDICE. Higher Education Governance in Europe. Policies, structures, funding and academic staff. 2008. Brussels: Eurydice. ISBN 978-92-79-08524-6, DOI: $\underline{10.2766 / 29900 .}$.

ELSEVIER. (2016). Scopus. [online] Available at: https://www.scopus.com/home.uri [Accessed: 5/5/2016] 
EUROSTAT. (2015). Population [online] Last update [11. 10. 2015]. Available at: ec.europa.eu/eurostat [Accessed: 17/11/2015]

FREEMAN, R. E. (2010). Strategic Management a Stakeholder Approach. Cambridge University Press. 276 pp. ISBN 978-0-521-15174-0.

FREY, B. S., EICHINGER, R. (1993). American and European Economics and Economists. Journal of Economic Perspectives. vol. 7, no. 4 (Fall, 1993), pp. 185-193. DOI: 10.1257/jep.7.4.185

HIRSCH, W. Z., WEBER, L. E. (2001). Governance in Higher Education The University in a State of Flux. Economica Ltd. London. 204 pp.

Leiden Ranking 2016. (2016). [online] Copyright (C) 2016 Centre for Science and Technology Studies, Leiden University, The Netherlands [cit. 2016-06-30]. Available at: http://www.leidenranking.com/ [Accessed: 30/6/2016]

MAREK, P. (2007). Vliv teorie zastoupení na teorii podnikových financí. Český finanční a účetní časopis. č. 2, pp. 6-16.

OECD. (2014). Education at a Glance 2014: OECD Indicators, OECD Publishing 2014. [online] ISBN 978-92-64-21132-2 (print), ISBN 978-92-64-21505-4 (PDF). [Accessed: 30/6/ 2016]

OECD. (2015). Education at a Glance 2015: OECD Indicators, OECD Publishing 2015. ISBN 978-92-64-24208-1 (print) ISBN 978-92-64-24209-8 (PDF).

ONS UK [Office for National Statistics - the UK]. (2016). 2011 Census: Religion, local authorities in England and Wales [online] Available at: http://www.ons.gov.uk/ons/rel/census/2011-census/key-statistics-for-local-authoritiesin-england-and-wales/rft-table-ks209ew.xls [Accessed: 5/5/2016]

ROSS, S. A. (1973). The Economic Theory of Agency: The Principal's Problem. The American Review. vol. 63, no. 2, pp. 134-139.

SABL [Statistische Ämter des Bundes und der Länder]: Zensus 2011 - Germany. [online] (C) Statistische Ämter des Bundes und der Länder 2014. Available at: <https://www.zensus2011.de/SharedDocs/Aktuelles/Ergebnisse/DemografischeGrundda ten.html?nn=3068736> [Accessed: 22/7/2016].

THOMSON REUTERS. Web of Science. [online] Available at: https://apps.webofknowledge.com/WOS_GeneralSearch_input.do?product=WOS\&sear ch_mode=GeneralSearch\&SID=Z18WU7UKNInHde3KeFG\&preferencesSaved $=[$ Accessed: 5/5/2016]. 


\section{Appendices}

\section{Appendix 1: Autonomy of a university and research - sources of data sets}

\begin{tabular}{|l|l|}
\hline Data sets & Source \\
\hline University autonomy indicators & University Autonomy Tool (EUA 2015) \\
\hline $\begin{array}{l}\text { Expenditures on tertiary education per capita } \\
\text { from 2008 to 2012 (average) }\end{array}$ & $\begin{array}{l}\text { Education at a Glance 2014 - OECD indicators, } \\
\text { Table B2.2. Trends in expenditure on educational } \\
\text { institutions as a percentage of GDP, by level of } \\
\text { education (1995, 2000, 2005, 2008, 2009, 2010, }\end{array}$ \\
& $\begin{array}{l}\text { 2011) From public and private sources, by year } \\
\text { (OECD 2014) }\end{array}$ \\
& $\begin{array}{l}\text { Education at a Glance 2015 - OECD indicators, } \\
\text { Table B2.1 Expenditure on educational institutions }\end{array}$ \\
& $\begin{array}{l}\text { as a percentage of GDP, by level of education } \\
\text { (2012) From public and private sources of funds }\end{array}$ \\
& (OECD 2014) \\
OECD Data \\
GDP per head of population, USD current prices, \\
USD PPPs (OECD 2016a)
\end{tabular}




\section{Appendix 2: Stakeholder involvement in internal governance of a university and research - sources of data sets}

\begin{tabular}{|c|c|}
\hline Data sets & Sources \\
\hline $\begin{array}{l}\text { The degree of stakeholder involvement in as- } \\
\text { pects of internal university governance }\end{array}$ & $\begin{array}{l}\text { The extent and impact of higher education govern- } \\
\text { ance reform across Europe } \\
\text { Final report to the Directorate-General for Education } \\
\text { and Culture of the European Commission } \\
\text { Contract: } 2006 \text { - } 1407 \text { / } 001-001 \text { S02-81AWB } \\
\text { Part Two: Summaries of the Quick Scan Surveys on } \\
\text { governance reform in } 32 \text { European countries } \\
\text { (CHEPS 2006b) }\end{array}$ \\
\hline $\begin{array}{l}\text { Expenditures on tertiary education per capita for } \\
\text { ARWU in the period 2005-2010 and for Leiden } \\
\text { ranking in the period 2005-2009 } \\
\text { (average) }\end{array}$ & $\begin{array}{l}\text { Education at a Glance } 2014-\text { OECD indicators, } \\
\text { Table B2.2. Trends in expenditures on educational } \\
\text { institutions as a percentage of GDP, by level of } \\
\text { education (1995, 2000, 2005, 2008, 2009, 2010, } \\
\text { 2011) From public and private sources, by year } \\
\text { (OECD 2014) } \\
\text { OECD Data } \\
\text { GDP per head of population, USD current prices, } \\
\text { USD PPPs (OECD 2016a) }\end{array}$ \\
\hline $\begin{array}{l}\text { Papers published in Nature and Science by } \\
\text { universities in a given country in international } \\
\text { comparisons per capita* }\end{array}$ & $\begin{array}{l}\text { Academic Ranking of World Universities } 2011- \\
\text { a partial indicator relating to the period 2006-2010 } \\
\text { (ARWU 2016) }\end{array}$ \\
\hline $\begin{array}{l}\text { Papers of universities in a given country indexed } \\
\text { in Science Citation Index-Expanded and Social } \\
\text { Science Citation Index in international compari- } \\
\text { sons per capita (average in the period 2006- } \\
2010)^{*}\end{array}$ & $\begin{array}{l}\text { Academic Ranking of World Universities 2007, 2008, } \\
2009,2010,2011 \text { - a partial indicator relating to the } \\
\text { period 2006-2010 } \\
\text { (ARWU 2016) }\end{array}$ \\
\hline $\begin{array}{l}\text { The number of publications by universities in a } \\
\text { given country that belong to the top } 1 \% \text { most } \\
\text { frequently cited taking into account co-authorship } \\
\text { (using fractional counting) per capita* }\end{array}$ & $\begin{array}{l}\text { CWTS Leiden Ranking } 2016 \text { - data relating to the } \\
\text { period 2006-2009. (Leiden ranking 2016) } \\
\text { based on Web of Science }\end{array}$ \\
\hline \multicolumn{2}{|c|}{$\begin{array}{l}\text { *Note: Number of population relates to 2011. The sources for calculation per capita are as follows: } \\
\text { EUROSTAT Population (EUROSTAT 2015) } \\
\text { Belgian Federal Government - Statistics Belgium (BFG 2016) } \\
\text { Ministry of Foreign Affairs of the Czech Republic - information about Belgium (MZV 2016) }\end{array}$} \\
\hline
\end{tabular}




\section{Appendix 3: Equations of regression models}

\section{Model 1}

Dependent variable: Ptop1

Number of observations: 15

\begin{tabular}{|l|l|l|l|l|}
\hline & coefficient & std. error & $t$-ratio & $p$-value \\
\hline constant & $-4,26794$ & 0,692754 & $-6,1608$ & $<0,0001$ \\
\hline Financial autonomy & 0,0348346 & 0,00747262 & 4,6616 & 0,0005 \\
\hline Expenditures on tertiary education per capita & $8,84935 \mathrm{e}-05$ & $9,90361 \mathrm{e}-06$ & 8,9355 & $<0,0001$ \\
\hline
\end{tabular}

\begin{tabular}{|l|c|l|l|}
\hline Mean of dependent variable & 2,352389 & S. D. dependent variable & 1,596211 \\
\hline Sum of squared residuals & 3,841898 & S. E. of regression & 0,565825 \\
\hline R-squared & 0,892295 & Adjusted R-squared & 0,874344 \\
\hline $\mathrm{F}(2,12)$ & 49,70755 & P-value $(\mathrm{F})$ & $1,56 \mathrm{e}-06$ \\
\hline Log-likelihood & $-11,06845$ & Akaike criterion & 28,13690 \\
\hline Schwarz criterion & 30,26105 & Hannan-Quinn criterion & 28,11427 \\
\hline
\end{tabular}

\section{Model 2}

Dependent variable: Ptop1

Number of observations: 15

\begin{tabular}{|l|l|l|l|l|}
\hline & coefficient & std. error & t-ratio & $p$-value \\
\hline constant & $-2,39993$ & 0,517832 & $-4,6346$ & 0,0006 \\
\hline $\begin{array}{l}\text { Autonomy in tuition fees for national/EU } \\
\text { students at doctoral level }\end{array}$ & 0,0153162 & 0,00303838 & 5,0409 & 0,0003 \\
\hline Expenditures on tertiary education per capita & $7,92573 \mathrm{e}-05$ & $9,53359 \mathrm{e}-06$ & 8,3135 & $<0,0001$ \\
\hline
\end{tabular}

\begin{tabular}{|l|r|l|r|}
\hline Mean of dependent variable & 2,352389 & S. D. dependent variable & 1,596211 \\
\hline Sum of squared residuals & 3,463985 & S. E. of regression & 0,537276 \\
\hline R-squared & 0,902889 & Adjusted R-squared & 0,886704 \\
\hline F(2, 12) & 55,78512 & P-value (F) & $8,39 \mathrm{e}-07$ \\
\hline Log-likelihood & $-10,29185$ & Akaike criterion & 26,58370 \\
\hline Schwarz criterion & 28,70785 & Hannan-Quinn criterion & 26,56107 \\
\hline
\end{tabular}




\section{Model 3}

Dependent variable: PUB

Number of observations: 15

\begin{tabular}{|l|l|l|l|l|}
\hline & coefficient & std. error & t-ratio & $p$-value \\
\hline constant & $-2,55032$ & 0,586882 & $-4,3455$ & 0,0010 \\
\hline $\begin{array}{l}\text { Autonomy in recruitment procedures for } \\
\text { senior academic staff }\end{array}$ & 0,0177107 & 0,0077814 & 2,2760 & 0,0420 \\
\hline Expenditures on tertiary education per capita & $5,65241 \mathrm{e}-05$ & $9,2008 \mathrm{e}-06$ & 6,1434 & $<0,0001$ \\
\hline
\end{tabular}

\begin{tabular}{|l|r|l|r|}
\hline Mean of dependent variable & 1,849550 & S. D. dependent variable & 1,137961 \\
\hline Sum of squared residuals & 2,557568 & S. E. of regression & 0,461661 \\
\hline R-squared & 0,858927 & Adjusted R-squared & 0,835415 \\
\hline F(2, 12) & 36,53111 & P-value $(F)$ & $7,88 \mathrm{e}-06$ \\
\hline Log-likelihood & $-8,016626$ & Akaike criterion & 22,03325 \\
\hline Schwarz criterion & 24,15740 & Hannan-Quinn criterion & 22,01063 \\
\hline
\end{tabular}

\section{Model 4}

Dependent variable: Ptop1

Number of observations: 15

\begin{tabular}{|l|l|l|l|l|}
\hline & coefficient & std. error & t-ratio & $p$-value \\
\hline const & $-2,18307$ & 0,554589 & $-3,9364$ & 0,0020 \\
\hline Overall inv. of students in internal governance & 0,201128 & 0,0721421 & 2,7879 & 0,0164 \\
\hline Expenditures on tertiary education per capita & $7,77714 \mathrm{e}-05$ & $1,2065 \mathrm{e}-05$ & 6,4460 & $<0,0001$ \\
\hline
\end{tabular}

\begin{tabular}{|l|r|l|r|}
\hline Mean of dependent variable & 1,844268 & S. D. dependent variable & 1,257838 \\
\hline Sum of squared residuals & 3,732457 & S. E. of regression & 0,557708 \\
\hline R-squared & 0,831493 & Adjusted R-squared & 0,803409 \\
\hline F $(2,12)$ & 29,60687 & P-value $(\mathrm{F})$ & 0,000023 \\
\hline Log-likelihood & $-10,85170$ & Akaike criterion & 27,70340 \\
\hline Schwarz criterion & 29,82755 & Hannan-Quinn criterion & 27,68078 \\
\hline
\end{tabular}




\section{Model 5}

Dependent variable: Ptop1

Number of observations: 15

\begin{tabular}{|l|l|l|l|l|}
\hline & coefficient & std. error & t-ratio & $p$-value \\
\hline const & $-2,05195$ & 0,547853 & $-3,7454$ & 0,0028 \\
\hline Involvement of students in quality assurance & 1,02774 & 0,365925 & 2,8086 & 0,0158 \\
\hline Expenditures on tertiary education per capita & $7,70254 \mathrm{e}-05$ & $1,20848 \mathrm{e}-05$ & 6,3737 & $<0,0001$ \\
\hline
\end{tabular}

\begin{tabular}{|l|r|l|r|}
\hline Mean of dependent variable & 1,844268 & S. D. dependent variable & 1,257838 \\
\hline Sum of squared residuals & 3,710758 & S. E. of regression & 0,556084 \\
\hline R-squared & 0,832473 & Adjusted R-squared & 0,804552 \\
\hline F $(2,12)$ & 29,81508 & P-value (F) & 0,000022 \\
\hline Log-likelihood & $-10,80797$ & Akaike criterion & 27,61595 \\
\hline Schwarz criterion & 29,74010 & Hannan-Quinn criterion & 27,59332 \\
\hline
\end{tabular}

\section{Model 6}

Dependent variable: $\mathrm{N}$ and $\mathrm{S}$

Number of observations: 15

\begin{tabular}{|l|r|r|r|r|}
\hline & \multicolumn{1}{|c|}{ coefficient } & \multicolumn{1}{c|}{ std. error } & \multicolumn{1}{|c|}{ t-ratio } & \multicolumn{1}{c|}{-value } \\
\hline const & $-0,760337$ & 0,182774 & $-4,1600$ & 0,0013 \\
\hline Involvement of students in quality assurance & 0,286076 & 0,121102 & 2,3623 & 0,0359 \\
\hline Expenditures on tertiary education per capita & $2,70817 \mathrm{e}-05$ & $3,87797 \mathrm{e}-06$ & 6,9835 & $<0,0001$ \\
\hline
\end{tabular}

\begin{tabular}{|l|r|l|r|}
\hline Mean of dependent variable & 0,616944 & S. D. dependent variable & 0,430102 \\
\hline Sum of squared residuals & 0,410469 & S. E. of regression & 0,184948 \\
\hline R-squared & 0,841507 & Adjusted R-squared & 0,815092 \\
\hline F(2, 12) & 31,85667 & P-value (F) & 0,000016 \\
\hline Log-likelihood & 5,704705 & Akaike criterion & $-5,409409$ \\
\hline Schwarz criterion & $-3,285259$ & Hannan-Quinn criterion & $-5,432036$ \\
\hline
\end{tabular}




\section{Model 7}

Dependent variable: $\mathrm{N}$ and $\mathrm{S}$

Number of observations: 15

\begin{tabular}{|l|r|r|r|r|}
\hline & \multicolumn{1}{|c|}{ coefficient } & \multicolumn{1}{|c|}{ std. error } & t-ratio & \multicolumn{1}{l|}{-value } \\
\hline const & 0,0673484 & 0,237003 & 0,2842 & 0,7811 \\
\hline Overall inv. of state in internal governance & $-0,0897599$ & 0,0216247 & $-4,1508$ & 0,0013 \\
\hline Expenditures on tertiary education per capita & $2,25497 \mathrm{e}-05$ & $3,32353 \mathrm{e}-06$ & 6,7848 & $<0,0001$ \\
\hline
\end{tabular}

\begin{tabular}{|l|r|l|r|}
\hline Mean of dependent variable & 0,616944 & S. D. dependent variable & 0,430102 \\
\hline Sum of squared residuals & 0,246883 & S. E. of regression & 0,143435 \\
\hline R-squared & 0,904672 & Adjusted R-squared & 0,888784 \\
\hline F(2, 12) & 56,94068 & P-value (F) & $7,50 \mathrm{e}-07$ \\
\hline Log-likelihood & 9,517596 & Akaike criterion & $-13,03519$ \\
\hline Schwarz criterion & $-10,91104$ & Hannan-Quinn criterion & $-13,05782$ \\
\hline
\end{tabular}

\section{Model 8}

Dependent variable: PUB

Number of observations: 15

\begin{tabular}{|l|r|r|r|r|}
\hline & \multicolumn{1}{|c|}{ coefficient } & \multicolumn{1}{l|}{ std. error } & t-ratio & \multicolumn{1}{c|}{-value } \\
\hline const & 0,685593 & 0,794439 & 0,8630 & 0,4066 \\
\hline Overall inv. of state in internal governance & $-0,293664$ & 0,0793904 & $-3,6990$ & 0,0035 \\
\hline Expenditures on tertiary education per capita & $6,04281 \mathrm{e}-05$ & $9,66909 \mathrm{e}-06$ & 6,2496 & $<0,0001$ \\
\hline
\end{tabular}

\begin{tabular}{|l|r|l|r|}
\hline Mean of dependent variable & 1,751072 & S. D. dependent variable & 1,193457 \\
\hline Sum of squared residuals & 1,788723 & S. E. of regression & 0,403251 \\
\hline R-squared & 0,903398 & Adjusted R-squared & 0,885834 \\
\hline $\mathrm{F}(2,12)$ & 51,43465 & P-value $(\mathrm{F})$ & $2,61 \mathrm{e}-06$ \\
\hline Log-likelihood & $-5,462253$ & Akaike criterion & 16,92451 \\
\hline Schwarz criterion & 18,84168 & Hannan-Quinn criterion & 16,74704 \\
\hline
\end{tabular}




\section{Model 9}

Dependent variable: Ptop1

Number of observations: 15

\begin{tabular}{|l|r|r|r|r|}
\hline & \multicolumn{1}{|c|}{ coefficient } & \multicolumn{1}{|c|}{ std. error } & t-ratio & \multicolumn{1}{c|}{-value } \\
\hline const & $-0,739461$ & 0,773195 & $-0,9564$ & 0,3578 \\
\hline Involvement of state in HRM & $-0,876157$ & 0,369528 & $-2,3710$ & 0,0353 \\
\hline Expenditure on tertiary education per capita & $7,01212 \mathrm{e}-05$ & $1,39342 \mathrm{e}-05$ & 5,0323 & 0,0003 \\
\hline
\end{tabular}

\begin{tabular}{|l|r|l|r|}
\hline Mean of dependent variable & 1,844268 & S. D. dependent variable & 1,257838 \\
\hline Sum of squared residuals & 4,188041 & S. E. of regression & 0,590765 \\
\hline R-squared & 0,810925 & Adjusted R-squared & 0,779413 \\
\hline F $(2,12)$ & 25,73348 & P-value (F) & 0,000046 \\
\hline Log-likelihood & $-11,71545$ & Akaike criterion & 29,43090 \\
\hline Schwarz criterion & 31,55505 & Hannan-Quinn criterion & 29,40827 \\
\hline
\end{tabular}

\section{Model 10}

Dependent variable: $\mathrm{N}$ and $\mathrm{S}$

Number of observations: 15

\begin{tabular}{|l|r|r|r|r|}
\hline & \multicolumn{1}{|c|}{ coefficient } & \multicolumn{1}{c|}{ std. error } & \multicolumn{1}{c|}{ t-ratio } & \multicolumn{1}{c|}{-value } \\
\hline const & $-0,348065$ & 0,234258 & $-1,4858$ & 0,1631 \\
\hline Involvement of state in HRM & $-0,279038$ & 0,112419 & $-2,4821$ & 0,0288 \\
\hline Expenditure on tertiary education per capita & $2,46908 \mathrm{e}-05$ & $4,11037 \mathrm{e}-06$ & 6,0070 & $<0,0001$ \\
\hline
\end{tabular}

\begin{tabular}{|l|r|l|r|}
\hline Mean of dependent variable & 0,616944 & S. D. dependent variable & 0,430102 \\
\hline Sum of squared residuals & 0,397346 & S. E. of regression & 0,181967 \\
\hline R-squared & 0,846575 & Adjusted R-squared & 0,821004 \\
\hline F(2, 12) & 33,10697 & P-value (F) & 0,000013 \\
\hline Log-likelihood & 5,948407 & Akaike criterion & $-5,896814$ \\
\hline Schwarz criterion & $-3,772663$ & Hannan-Quinn criterion & $-5,919440$ \\
\hline
\end{tabular}




\section{Model 11}

Dependent variable: $\mathrm{N}$ and $\mathrm{S}$

Number of observations: 15

\begin{tabular}{|l|r|r|r|r|}
\hline & \multicolumn{1}{|c|}{ coefficient } & \multicolumn{1}{|c|}{ std. error } & t-ratio & \multicolumn{1}{l|}{-value } \\
\hline const & $-0,457713$ & 0,194415 & $-2,3543$ & 0,0364 \\
\hline Inv. of state in finance/resources allocation & $-0,295011$ & 0,103987 & $-2,8370$ & 0,0150 \\
\hline Expenditure on tertiary education per capita & $2,74711 \mathrm{e}-05$ & $3,59318 \mathrm{e}-06$ & 7,6453 & $<0,0001$ \\
\hline
\end{tabular}

\begin{tabular}{|l|r|l|r|}
\hline Mean of dependent variable & 0,616944 & S. D. dependent variable & 0,430102 \\
\hline Sum of squared residuals & 0,359934 & S. E. of regression & 0,173189 \\
\hline R-squared & 0,861020 & Adjusted R-squared & 0,837857 \\
\hline F $(2,12)$ & 37,17176 & P-value $(F)$ & $7,21 \mathrm{e}-06$ \\
\hline Log-likelihood & 6,690050 & Akaike criterion & $-7,380100$ \\
\hline Schwarz criterion & $-5,255950$ & Hannan-Quinn criterion & $-7,402727$ \\
\hline
\end{tabular}

\section{Model 12}

Dependent variable: Ptop1

Number of observations: 15

\begin{tabular}{|l|r|r|r|r|}
\hline & \multicolumn{1}{|c|}{ coefficient } & \multicolumn{1}{l|}{ std. error } & \multicolumn{1}{l|}{-ratio } & \multicolumn{1}{l|}{-value } \\
\hline const & $-0,746191$ & 0,452056 & $-1,6507$ & 0,1270 \\
\hline Involvement of state in new study programmes & $-1,25892$ & 0,244487 & $-5,1492$ & 0,0003 \\
\hline Inv. of external subjects in mission/strategy & 0,858068 & 0,282578 & 3,0366 & 0,0113 \\
\hline Expenditures on tertiary education per capita & $6,44238 \mathrm{e}-05$ & $8,19156 \mathrm{e}-06$ & 7,8647 & $<0,0001$ \\
\hline
\end{tabular}

\begin{tabular}{|l|r|l|r|}
\hline Mean of dependent variable & 1,844268 & S. D. dependent variable & 1,257838 \\
\hline Sum of squared residuals & 1,371519 & S. E. of regression & 0,353106 \\
\hline R-squared & 0,938081 & Adjusted R-squared & 0,921194 \\
\hline F(2, 12) & 55,55042 & P-value (F) & $6,22 \mathrm{e}-07$ \\
\hline Log-likelihood & $-3,343092$ & Akaike criterion & 14,68618 \\
\hline Schwarz criterion & 17,51838 & Hannan-Quinn criterion & 14,65601 \\
\hline
\end{tabular}




\section{Model 13}

Dependent variable: $\mathrm{N}$ and $\mathrm{S}$

Number of observations: 15

\begin{tabular}{|l|r|r|r|r|}
\hline & \multicolumn{1}{|c|}{ coefficient } & \multicolumn{1}{l|}{ std. error } & t-ratio & \multicolumn{1}{l|}{-value } \\
\hline const & $-0,478495$ & 0,193457 & $-2,4734$ & 0,0309 \\
\hline Involvement of state in new study programmes & $-0,294674$ & 0,105366 & $-2,7967$ & 0,0174 \\
\hline Inv. of external subjects in mission/strategy & 0,284477 & 0,122968 & 2,3134 & 0,0411 \\
\hline Expenditures on tertiary education per capita & $2,40221 \mathrm{e}-05$ & $3,41675 \mathrm{e}-06$ & 7,0307 & $<0,0001$ \\
\hline
\end{tabular}

\begin{tabular}{|l|r|l|r|}
\hline Mean of dependent variable & 0,616944 & S. D. dependent variable & 0,430102 \\
\hline Sum of squared residuals & 0,260152 & S. E. of regression & 0,153786 \\
\hline R-squared & 0,899549 & Adjusted R-squared & 0,872153 \\
\hline F(2, 12) & 32,83524 & P-value $(F)$ & $8,75 e-06$ \\
\hline Log-likelihood & 9,124959 & Akaike criterion & $-10,24992$ \\
\hline Schwarz criterion & $-7,417717$ & Hannan-Quinn criterion & $-10,28009$ \\
\hline
\end{tabular}

\section{Model 14}

Dependent variable: PUB

Number of observations: 15

\begin{tabular}{|l|r|r|r|r|}
\hline & \multicolumn{1}{|c|}{ coefficient } & \multicolumn{1}{|c|}{ std. error } & \multicolumn{1}{c|}{ t-ratio } & \multicolumn{1}{c|}{-value } \\
\hline const & $-0,985551$ & 0,578279 & $-1,7043$ & 0,1141 \\
\hline Involvement of state in new study programmes & $-0,820345$ & 0,321246 & $-2,5536$ & 0,0253 \\
\hline Expenditures on tertiary education per capita & $7,20055 \mathrm{e}-05$ & $1,00735 \mathrm{e}-05$ & 7,1480 & $<0,0001$ \\
\hline
\end{tabular}

\begin{tabular}{|l|r|l|r|}
\hline Mean of dependent variable & 1,799892 & S. D. dependent variable & 1,165484 \\
\hline Sum of squared residuals & 2,658762 & S. E. of regression & 0,470705 \\
\hline R-squared & 0,860190 & Adjusted R-squared & 0,836888 \\
\hline F(2, 12) & 36,91529 & P-value (F) & $7,47 e-06$ \\
\hline Log-likelihood & $-8,307657$ & Akaike criterion & 22,61531 \\
\hline Schwarz criterion & 24,73946 & Hannan-Quinn criterion & 22,59269 \\
\hline
\end{tabular}

